\title{
Pengelompokan Data Penjualan Mie Berdasarkan Bulan Dengan Menggunakan Algoritma K-Medoids
}

\author{
Riahta Ulina Br. Barus ${ }^{* 1}$, Indra Gunawan ${ }^{2}$, Bahrudi Effendi Damanik ${ }^{3}$, \\ Iin Parlina ${ }^{4}$, Widodo Saputra ${ }^{5}$
}

1,2,3,4,5 Teknik Informatika, STIKOM Tunas Bangsa Pematangsiantar, Indonesia

Email: ${ }^{1}$ riahtabarus@gmail.com, ${ }^{2}$ indra@amiktunasbangsa.ac.id, ${ }^{3}$ bahrudiefendi@gmail.com, 4iin@amiktunasbangsa.ac.id, ${ }^{5}$ widodo@amiktunasbangsa.ac.id

\begin{abstract}
Abstrak
Mie merupakan salah satu keanekragaman kuliner yang memiliki potensi sangat besar untuk dikembangkan sebagai peningkatan ekonomi di pematangsiantar. Penjualana Mie di Kota pematangsiantar juga sangat pesat, namun para pedagang masih mneggunakan cara manual dalam pengelompokan data hasil penjualan dari berbagai macam jjenis mie yang di jual sehingga tingkat akurasi keuntungannya menjadi tidak Nampak dengan jelas. Berdasarkan itu makan penulis membuat penelitian ini dengan menggunakan Algoritma K-Medoids untuk mengcluster data penjualan mie dari tahun 2018-2019 berdasarkan tahun dan bulan. Hasil yang diperoleh dari produksi mie di tahun 2018 terbanyak adalah mie pangsit dengan centroid 304670 pada bulan Januari dan mie pangsit dengan centroid 290476 pada bulan Desember, sedangkan di tahun 2019 adalah mie pangsit centroid 311532 bulan Januari dan 311532 pada bulan Desember. Tingkat akurasi dari pengolahan RapidMiner dengan pengolahan yang dilakukan penulis menunjukkan 12 data yang digunakan. Untuk Cluster $\mathrm{C} 1$ atau kelompok Tinggi diperoleh akurasi sebesar 17\% dengan jumlah data yang sama 2 data, Cluster C2 atau kelompok Sedang diperoleh akurasi sebesar 8\% dengan jumlah data yang sama 1 data dan Cluster C3 atau kelompok Rendah diperoleh akurasi sebesar $75 \%$ dengan jumlah data yang sama 9 data.
\end{abstract}

Kata kunci: data mining, K-Medoids, kuliner, mie, pengelompokan, Rapidminer

\section{Abstract}

Noodles are one of the culinary diversity that has enormous potential to be developed as an economic improvement in Pemangsiantar. Sales of noodles in Pematangsiantar City are also very fast, but traders still use manual methods in grouping sales data from various types of noodles that are sold so that the accuracy of profits is not clearly visible. Based on that, the author made this research using the K-Medoids Algorithm to cluster noodle sales data from 2018-2019 based on year and month. The results obtained from the most noodle production in 2018 were wonton noodles with a centroid of 304670 in January and wonton noodles with a centroid of 290476 in December, while in 2019 were wonton noodles centroid 311532 in January and 311532 in December. The accuracy level of RapidMiner processing with the processing carried out by the author shows 12 data used. For Cluster C1 or the High group, an accuracy of $17 \%$ was obtained with the same amount of data 2 data, Cluster C2 or the Medium group obtained an accuracy of $8 \%$ with the same amount of data 1 data and Cluster C3 or the Low group obtained an accuracy of $75 \%$ with the amount of data the same 9 data.

Keywords: culinary, data mining, grouping, K-Medoids, noodles, Rapidminer.

\section{PENDAHULUAN}

Data Mining merupakan proses yang dibantu oleh komputer untuk menggali dan menganalisis sejumlah besar himpunan data dan mengekstrak informasi dan pengetahuan. Data Mining memilki 5 fase, yaitu Estimasi, Klustering, Prediksi, Klasifikasi dan Asosiasi. Data Mining Klustering memiliki salah satu metode yaitu K-Medoids. Data Mining Algoritma K-Medois merupakan salah satu metode yang banyak digunakan peneliti dengan membagi rangkaian data-data menjadi beberapa kelompok yang menggunakan nilai tengah yang disebut medoid dan perhitungan jarak dihitung dari jarak antar masing-masing data. K-Medoids dapat digunakan untuk mengelompokkan beberapa data, salah satunya mengelompokkan data penjualan mie di pematangsiantar. 
Mie merupakan salah satu keanekaragaman kuliner di Pematangsiantar membuat kuliner mi di Pematangsiantar menyimpan potensi yang sangat besar untuk dikembangkan sebagai peningkatan ekonomi di Pematangsiantar. Dalam era otonomi daerah, sektor wisata kuliner memegang peranan penting dalam meningkatkan perekonomian suatu daerah karena memiliki keterkaitan sumber pertumbuhan ekonomi daerah. Pengembangan wisata kuliner memberikan efek ganda terhadap sektor ekonomi lainnya melalui peningkatan nilai tambah dan kenaikan pendapatan masyarakat. Peningkatan intensitas pemakaian tenaga kerja dalam pengembangan kuliner tidak hanya diharapkan dapat meningkatkanpendapatan masyarakat, tetapi juga mampu menciptakan kesempatan kerja dan mengurangi tingkat kemiskinan. Pematangsiantar merupakan salah satu wilayah daerah yang memiliki banyak ciri khas wisata kuliner berbagai jenis mie, yaitu mie kuning, mie hun, mie lidi, mie ktiaw, ifu mie dan mie pangsit.. Keberagaman jenis mie yang dijual merupakan kuliner mie menjadi dominan masyarakat di Kota Pematangsiantar. Banyak berbagai macam mie yang dijual di wilayah Pematangsiantar dengan berbagai variasi, harga dan ukuran.

Dari penjelasan diatas banyak cabang kecerdasan buatan dalam ilmu komputer yang dapat menyelesaikan permasalahan tersebut secara kompleks diantaranya sistem pendukung keputusan, sistem pakar, data mining dan lain sebagainya. Beberapa penelitian tentang data mining, salah satunya yang dilakukan oleh Pramesti, dkk [1] dalam penelitian ini metode yang digunakan dalam penelitian ini adalah $K$-Medoids Clustering yang dapat diimplementasikan pada pengelompokan data potensi kebakaran hutan/lahan berdasarkan persebaran titik panas (hotspot) menghasilkan jumlah cluster dan jumlah data mempengaruhi terhadap hasil kualitas dari cluster berdasarkan proses pengujian yang dengan jumlah 2 cluster dan jumlah data 7352. Penelitian selanjutnya dilakukan oleh Mustafa [2] Dalam penelitian ini dilakukan pengujian model dengan menggunakan K-Medoids Chebyshev dalam pengelompokan data EDGI E-government Surve 2014 kedalam 4 status EDGI yeng menghasilkan model mendapatkan nilai Bouldin Index dari setiap algoritma yang lebih optomal dalam penentuan pengelompokan EDGI E-govermnet Surve 2014 ke dalam 4 status EDGI di bandingkan menggunakan mahattan atau ecludian.

Penelitian ini menjadi salah satu acuan penulis dalam melakukan penelitian sehingga penulis dapat memperkarya teori yang digunakan dalam mengkaji penelitian mengelompokkan data penjualan mie di kota Pematangsiantar. Tingkat penjualan antar perusahaan pembuat kuliner mie cenderung berubah karena banyaknya usaha kuliner mie. Seiring berubahnya tingkat penjualan berdampak pada usaha kuliner mie sehingga membuat pemborosan modal yang tidak terpakai dalam penjualan mie. Pemborosan modal tersebut karena banyaknya pengusaha kuliner mie di Kota Pematangsiantar, sehingga mengakibatkan dampak ketidaksesuaian kebutuhan konsumen dengan tingkat produksi pembuatan mie.

Berdasarkan beberapa uraian tersebut menjadi salah satu acuan penulis dalam melakukan penelitian sehingga penulis dapat memperkarya teori yang digunakan dalam mengkaji penelitian mengelompokkan data penjualan mie di kota Pematangsiantar. Untuk mengetahui pengelompokkan tingkat penjualan mie di Kota Pematangsiantar pada berdasarkan bulan, penulis menggunakan teknik Data Mining dalam proses pengolahan data dengan Algoritma $K$-Medoids.

Metode K-Medoids clustering sangat cocok dalam mengelompokan data- data hasil penjualan mie dimana K-Medoids ini menggunakan kelompok metode partitional Clustering yang dapat meminimalisir jarak antar titik berlabel yang ada dalam cluster yang juga menggunakan objek sebagai perwakilan tidak dengan angka rata-rata sehingga algoritma ini dapat diterapkan pada data penjualan mie di Kota Pematangsiantar, dengan adanya pengelompokan ini dapat mempermudah penjual mie dalam mengelompokan data-data hasil penjualan masing-masing mienya yang berbeda dengan mudah dan akurat. Diharapkan penelitian ini dapat memberikan informasi kepada pengusaha Mie serta pemerintah untuk mengatasi ketidaksesuaian kebutuhan konsumen dan tingkat produksi mie di kota Pematangsiantar.

\section{TINJAUAN PUSTAKA}

\subsection{Data Mining}


Data mining adalah proses analitik yang dirancang untuk memeriksa sejumlah data yang besar dalam mencari suatu pengetahuan tersembunyi yang berharga dan konsisten.[3] Istilah lain data mining adalah proses yang mempekerjakan satu atau lebih teknik pembelajaran komputer (machine learning) untuk menganalisis dan mengekstraksi pengetahuan secara otomatis. Data mining digunakan untuk mencari pengetahuan yang terdapat dalam basis data yang besar sehingga sering disebut Knowledge Discovery Databases (KDD) yaitu tahapan yang dilakukan dalam menggali pengetahuan dari sekumpulan data. Proses penggalian informasi tersembunyi dalam suatu basis data yang besar sering menggunakan istilah data mining dan knowledge discovery in databases (KDD). [4] Merupakan tahapan untuk menentukan pola atau informasi delam sekumpulan data dengan menggunakan teknik dan algoritma tertentu. [5]

\subsection{Clustering}

Clustering adalah salah satu teknik data mining yang bertujuan untuk mengidentifikasi sekelompok objek yang mempunyai kemiripan karakteristik tertentu yang dapat dipisahkan dengan kelompok objek lainnya, sehingga objek yang berada dalam kelompok yang sama relatif lebih homogen dari pada objek yang berada pada kelompok yang berbeda.[6]

Hal ini dapat dilakukan dengan menerapkan berbagai persamaan dan langkah-langkah mengenai jarak algoritma yaitu dengan Euclidean Distance. Analisis kluster ialah metode yang dipakai untuk membagi rangkaian data menjadi beberapa grup berdasarkan kesamaan-kesamaan yang telah ditentukan sebelumnya.[7]

Tujuan dari pengelompokkan sekumpulan data objek kedalam beberapa kelompok yang mempunyai karakteristik tertentu dan dapat dibedakan satu sama lainnya adalah untuk analisis dan interpretasi lebih lanjut sesuai dengan tujuan penelitian yang dilakukan. Model yang diambil diasumsikan bahwa data yang dapat digunakan adalah data yang berupa data interval, frekuensi dan biner.

\subsection{Metode K-Medoids Clustering}

Metode $k$-medoids adalah metode pengelompokkan yang berkaitan dengan metode $k$-means dan metode medoidshift.[8] Metode k-medoids di usulkan pada tahun 1987. Metode k-medoids dikembangkan oleh Leonard Kaufman dan Peter J. Rousseeuw. Metode k-means dan $k$-medoids yang partitional (melanggar dataset ke dalam kelompok) dan kedua upaya untuk meminimalkan jarak antara titik berlabel berada dalam cluster dan titik yang ditunjuk sebagai pusat cluster. Berbeda dengan $k$ means, metode $k$-medoids memilih datapoint sebagai pusat (medoids atau eksemplar) dan bekerja dengan matriks sewenang-wenang dari jarak antara datapoints.

Penggunaan Algoritma K-Medoids bekerja dengan baik karena setiap objek pada setiap cluster memiliki mutu yang baik, dimana setiap objek telah dikelompokan sesuai dengan tingkat kemiripan yang tinggi serta K-Medoids lebih baik dalam melakukan pengelompokan data dibandingkan dengan algoritma K-Means berdasarkan nilai validitasnya.[9]

Algoritma $K$-Medoids merupakan algoritma yang mirip dengan $K$-Means karena kedua algoritma partitional yang memecah dataset menjadi kelompok - kelompok. Perbedaannya terletak pada penentuan pusat cluster, di mana algoritma K-Means menggunakan nilai rata -rata (means) dari setiap cluster sebagai pusat cluster dan algoritma $K$-Medoids menggunakan objek data sebagai perwakilan (medoid) sebagai pusat cluster.[10]

Perbedaan dari kedua metode ini yaitu metode $k$-medoids menggunakan objek sebagai perwakilan (medoid) sebagai pusat cluster untuk setiap cluster, sedangkan k-means menggunakan nilai rata-rata (mean) sebagai pusat cluster. Metode $k$-medoids memiliki kelebihan untuk mengatasi kelemahan pada pada metode $k$-means yang sensitive terhadap noise dan outlier, dimana objek dengan nilai yang besar yang memungkinkan menyimpang pada dari distribusi data. Kelebihan lainnya yaitu hasil proses clustering tidak bergantung pada urutan masuk dataset.

Langkah-langkah metode $K$-Medoids adalah sebagai berikut :

a. Inisialisasi pusat cluster sebanyak $k$ (jumlah cluster) 
Alokasikan setiap data (objek) ke cluster terdekat menggunakan persamaan ukuran jarak Euclidian Distance dengan persamaan:

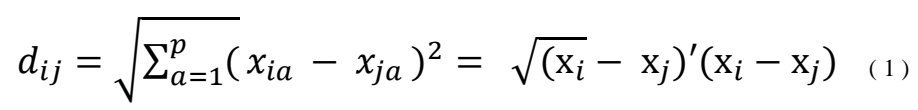

dimana $i=1, \ldots ., n ; j=1, \ldots \ldots, n$ dan $p$ adalah banyak variable, serta $V$ adalah matrik varian kovarian.

b. Pilih secara acak objek pada masing-masing cluster sebagai kandidat medoid baru.

c. Hitung jarak setiap objek yang berada pada masing-masing cluster dengan kandidat medoid baru.

d. Hitung total simpangan $(S)$ dengan menghitung nilai total distance baru - total distance lama. Jika $S<0$, maka tukar objek dengan data cluster untuk membentuk sekumpulan $k$ objek baru sebagai medoid.

e. Ulangi langkah 3 sampai 5 hingga tidak terjadi perubahan medoid, sehingga didapatkan cluster beserta anggota cluster masing-masing.

\subsection{Rapid Miner}

RapidMiner adalah salah satu alat penambangan data yang digunakan untuk menganalisis informasi yang diakses web. Ini digunakan untuk penelitian, pendidikan, pembuatan prototipe cepat, aplikasi pengembangan, dan aplikasi industri.[11]

Dengan menggunakan Rapid Miner, tidak dibutuhkan kemampuan koding khusus, karena semua fasilits sudah disediakan. Rapid Miner dikhususkan untuk penggunaan data mining. Model yang disediakan juga cukup banyak dan lengkap, seperti Model Bayesian, Modelling, Tree Induction, Neural Network dan lain-lain[12]

Pengaruh dalam penilaian akurasi ini dinilai baik dengan data dan juga dengan algoritma yang dipakai. Akurasi dari sebuah algoritma tentunya dapat dihitung baik menggunakan manual seperti Confussion Matrix atau dapat dilihat dengan bantuan software seperti Rapidminer. Terdapat beberapa jenis aplikasi atau Software data mining terutama pada klasifikasi seperti Rapidminer, Weka, Orange, KNIME, SPSS Climatte dan sebagainya. Aplikasi yang dianggap mirip, mudah digunakan dan tidak perlu bingung dengan penggunaan bahasa pemogramanyang rumit adalah Rapidminer dan Weka. Langkah-langkah keduanya hampir sama yaitu hanya memasukkan data (import data) ke dalam aplikasi kemudian memilih algoritma lalu mendapatkan hasilnya, kedua aplikasi bersifat terbuka sehingga dapat digunakan tanpa pembayaran[13]

\subsection{Unifield Modelling Language (UML)}

UML (Unified Modelling Language) adalah bahasa spesifikasi standar untuk mendokumentasi, merancang dan membuat software orientasi objek. UML ini merupakan bahasa visual untuk pemodelan bahasa berorientasi objek, sehingga semua elemen dan diagram berbasiskan pada paradigma object oriented. UML menawarkan sebuah standard untuk merancang model sebuah sistem. UML mendefenisikan notasi dan syntax/semantik.[14] Pemilihan UML karena UML merupakan pemrograman berorientasi objek yang memiliki kemampuan dalam menganalisa dan menjabarkan sistem secara rinci. [15]

\section{METODE PENELITIAN}

Pada metode penelitian ini penulis menjelaskan bagaimana menguraikan cara ilmiah untuk menyelesaikan masalah-masalah penelitian.

\subsection{Rancangan Penelitian}

Flowchart penelitian pada skripsi ini dapat dideskripsikan sesuai gambar 1.

Pada gambar 1 diatas dijelaskan bahwasanya rancangan penelitian yang dilakukan untuk menentukan pengelompokkan data penjualan mie berdasarkan bulan di Kota Pematangsiantar terdiri dari : 




Gambar 1. Rancangan Penelitian

a. Identifikasi Masalah

Mengidentifikasi masalah yang terkait dalam pengelompokkan data penjualan mie berdasarkan bulan di Kota Pematangsiantar dari tahun 2018-2019.

b. Mempelajari Literatur

Penelitian ini dilandasi rujukan atau referensi yang terkait guna mendapatkan informasi pendukung dalam penelitian.Pengumpulan Data

c. Analisa Hasil

Proses yang dilakukan untuk mengelompokkan data penjualan mie berdasarkan bulan di Kota Pematangsiantar dengan menggunakan metode K-Medoids.

d. Pengujian

Penulis melakukan pengujian dengan menggunakan aplikasi RapidMiner untuk mengelompokkan data penjualan mie.

e. Keputusan

Hasil yang diberikan oleh sistem dan analisa penulis dapat memberikan masukan untuk pihak pengusaha mie untuk melihat data kebutuhan masyarakat konsumsi mie di Kota Pematangsiantar supaya tidak terjadi pemborosan modal.

\subsection{Prosedur pengumpulan data}

Penulis mengumpukan data dengan menggunakan metode Studi Kepustakaan (Libarry Research) yaitu memanfaatkan perpustakaan, buku, prosiding atau jurnal sebagai referensi dalam menentukan 
parameter yang digunakan Penelitian Lapangan (Field Work Research) Yaitu penelitian yang dilakukan secara langsung dengan menggunakan beberapa teknik wawancara dengan penjual mie yang ada di Kota Pematangsiantar

\subsection{Analisis Data}

Data yang yang di dapatkan dikumpulkan dari melakukan isian kuesioner terhadap penjual mie yang ada di Kota Pematangsiantar yang menggunakan beberapa parameter, yang terdiri dari bulan dari tahun 2018 dan 2019.

Berikut data yang dikumpulkan sebanyak 12 data dengan data perbulan dari \pm 80 usaha mie di Kota Pematangsiantar.

Tabel 1.Data Penelitian penjualan Mie Tahun 2018

\begin{tabular}{lcccccc}
\hline BULAN & MIE KUNING & MIE HUN & MIE LIDI & MIE KTIAW & IFU MIE & MIE PANGSIT \\
\hline Januari & 204750 & 184750 & 134750 & 198750 & 201608 & 304670 \\
Februari & 176653 & 176653 & 176653 & 176653 & 176653 & 176653 \\
Maret & 182082 & 182082 & 150085 & 182082 & 151698 & 182082 \\
April & 150085 & 187511 & 136716 & 150085 & 126743 & 150085 \\
Mei & 136716 & 192940 & 170741 & 136716 & 101788 & 136716 \\
Juni & 170741 & 198369 & 344265 & 170741 & 170741 & 100463 \\
Juli & 168879 & 198332 & 168879 & 168879 & 168879 & 164579 \\
Agustus & 167017 & 172652 & 153482 & 193635 & 153432 & 153983 \\
September & 165155 & 165155 & 165155 & 165155 & 165155 & 165155 \\
Oktober & 173293 & 173293 & 176828 & 173293 & 168879 & 173293 \\
November & 181431 & 165155 & 188501 & 136716 & 167017 & 150085 \\
Desember & 240088 & 240088 & 240088 & 240088 & 240088 & 290476 \\
Jumlah & 2116890 & 2236980 & 2206143 & 2092793 & 1992681 & 2148240 \\
\hline
\end{tabular}

Tabel 2.Data Penelitian penjualan Mie Tahun 2019

\begin{tabular}{lcccccc}
\hline BULAN & MIE KUNING & MIE HUN & MIE LIDI & MIE KTIAW & IFU MIE & MIE PANGSIT \\
\hline Januari & 217456 & 165155 & 134750 & 240088 & 240641 & 311532 \\
Februari & 176653 & 173293 & 176653 & 181431 & 176653 & 176653 \\
Maret & 182082 & 181431 & 150085 & 172353 & 151698 & 182082 \\
April & 184750 & 172652 & 136716 & 150085 & 126743 & 150085 \\
Mei & 176653 & 165155 & 170741 & 136716 & 101788 & 136716 \\
Juni & 182082 & 173293 & 344043 & 170741 & 170741 & 193643 \\
Juli & 187511 & 198332 & 168879 & 168879 & 243253 & 153532 \\
Agustus & 167017 & 172652 & 153482 & 193635 & 153432 & 153983 \\
September & 165155 & 165155 & 165155 & 165155 & 165155 & 165554 \\
Oktober & 173293 & 173293 & 136716 & 173293 & 168879 & 173293 \\
November & 181431 & 154383 & 170741 & 136716 & 167017 & 150085 \\
Desember & 240088 & 193464 & 201036 & 233872 & 269485 & 306953 \\
Jumlah & 2234171 & 2088258 & 2108997 & 2122964 & 2135485 & 2254111 \\
\hline
\end{tabular}

\subsection{Instrumen Penelitian}

Penelitian ini menggunakan penelitian dengan metode kuantitatif. Metode kuantitatif merupakan penelitian yang menggunakan data berupa angka sebagai alat menganalisis keterangan dengan menggunakan teknik wawancara. Alur instrumen penelitian dapat dilihat pada gambar 3 sebagai berikut : 


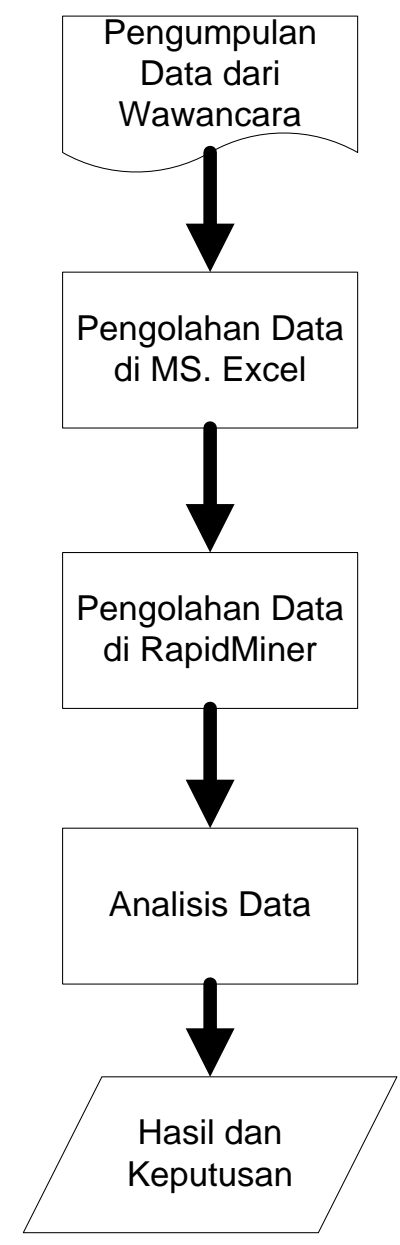

Gambar 2. Alur instrument penelitian

Pada gambar 2 diatas menunjukkan alur penelitian yang terdiri dari pengguna dan sistem. menjelaskan penulis sebagai pengguna melakukan analisa masalah dan tujuan masalah, kemudian mengumpulkan data yang diperoleh dari hasil melakukan wawancara, data yang telah dikumpulkan kemudian diolah menggunakan sistem yaitu software RapidMiner, hasil yang telah diperoleh dari sistem software RapidMiner menghasilkan pengelompokkan data penjualan mie di Kota Pematangsiantar. Penulis sebagai pengguna membua keputusan dari hasil penelitian pengelompokkan data penjualan mie dan membuat keputusan terhadap penelitian.

\subsection{Pemodelan Algoritma}

Permodelan yang digunakan menggunakan RapidMiner. Pada lembar main process operator $K$ Medoids menggunakan parameter yang digunakan dimana $k$ merupakan jumlah cluster yang digunakan, max runs merupakan penentukan jumlah maksimum berjalan $K$-Medoids dengan inisialisasi acak yang dilakukan, max optimization steps merupakan jumlah iterasi maksimum yang dilakukan untuk satu kali K-Medoids. Measure types merupakan jenis pengukuran yang akan digunakan untuk mengukur jarak antara titik dan mixed measure merupakan parameter yang tersedia ketika parameter tipe pengukuran diatur ke "mixed measure"

\section{HASIL DAN PEMBAHASAN}

Bagian ini menyajikan hasil penelitian sesuai data yang digunakan pada saat pengumpulan data. Data yang telah dikumpulkan untuk diolah atau ditransformasikan ke format data Ms.Excel 2010. Data yang ditransformasikan ersebut digunakan sebagai syarat dalam pengolahan Algoritma K-Medoids. 


\subsection{Algoritma K-Medoids}

Penulis menentukan analisa pengelompokkan tingkat penjualan mie di Kota Pematangsiantar menggunakan Algoritma K-Medoids. Berikut langkah-langkah dalam pengolahan data menggunakan Algoritma K-Medoids menggunakan data tahun 2018 dan tahun 2019.

a. Menentukan Data yang diolah

Data yang digunakan adalah data pembuatan mie tahun 2018 dan tahun 2019 di Kota Pematangsiantar.data dapat dilihat pada tabel 1 dan tabel 2.

b. Menentukan Jumlah Cluster, atau k yang digunakan sebanyak 3 yaitu Cluster Tinggi, Cluster Sedang dan Cluste Rendah

c. Menentukan Pusat Medoid

Menentukan Pusat Medoid dilakukan secara acak pada masing-masing Cluster. Pusat Medoid yang digunakan adalah :

Pusat Medoid awal Rendah tahun $2018=(136716,192940,170741,136716,101788,136716)$

Pusat Medoid awal Sedang tahun $2018=(167017,172652,153482,193635,153432,153983)$

Pusat Medoid awal Tinggi tahun $2018=(204750,184750,134750,198750,201608,304670)$

Pusat Medoid awal Rendah tahun $2019=(150335,187761,136966,150335,126993,150335)$

Pusat Medoid awal Sedang tahun $2019=(176903,169346,172366,170001,180362,173256)$

Pusat Medoid awal Tinggi tahun $2019=(205000,185000,135000,199000,201858,304920)$

d. Menghitung Nilai Euclidian

Untuk menghitung jarak antara titik Medoid dengan titik tiap objek menggunakan Euclidian Distance. Rumus untuk menghitung Nilai Euclidian adalah :

$$
D_{(i, f)}=\sqrt{\left(X_{1 i}-X_{1 j}\right)^{2}+\left(X_{2 i}-X_{2 j}\right)^{2}+\cdots+\left(X_{k i}-X_{k j}\right)^{2}}
$$

Sehingga didapat tabel jarak dari Medoid dan mencari nilai minimal dari ketiga Medoid. Tabel Jarak dari Medoid adalah sebagai berikut :

Tabel 3. Hasil Jarak Medoid Iterasi 1 tahun 2018

\begin{tabular}{lcccc}
\hline BULAN & C1 & C2 & C3 & Jarak Dekat \\
\hline Januari & 219116 & 164240 & 0 & 0 \\
Februari & 103392 & 44579 & 141811 & 44579 \\
Maret & 95968 & 35404 & 136209 & 35404 \\
April & 48437 & 58418 & 186733 & 48437 \\
Mei & 0 & 88502 & 219116 & 0 \\
Juni & 196276 & 201895 & 297786 & 196276 \\
Juli & 85901 & 43171 & 155644 & 43171 \\
Agustus & 88502 & 0 & 164240 & 0 \\
September & 85117 & 35627 & 157474 & 35627 \\
Oktober & 94540 & 40126 & 147887 & 40126 \\
November & 86720 & 70213 & 180992 & 70213 \\
Desember & 232468 & 171296 & 48314 & 48314 \\
\hline
\end{tabular}

Dari tabel 3 dapat dilihat hasil jarak Medoid iterasi 1 untuk tahun 2018 yang akan digunakan untuk menentukan nilai Cost. Nilai Jarak Dekat ini yang akan digunakan sebagai letak cluster atau kelompok berdasarkan nilai terkecil perbaris.

e. Cara Menghitung Nilai Cost

Nilai Cost diperoleh dari total penjumlahan nilai jarak dekat Medoid yang diperoleh yaitu : 
Cost $=(0+4459+35404+48437+0+196276+43171+0+35627+40126+70213+$ $48314)=562147$

f. Lakukan Ulang Langkah d dan e dengan nilai Pusat Medoid baru

Mengulangi proses meghitungan nilai jarak dekat Medoid dengan nilai pusat Medoid baru secara acak. Untuk data tahun 2018 yaitu :

Pusat Medoid baru Rendah tahun $2018=(136716,192940,170741,136716,101788,136716)$

Pusat Medoid baru Sedang tahun $2018=(170741,198369,344265,170741,170741,100463)$

Pusat Medoid baru Tinggi tahun $2018=(2040088,178573,149846,196338,226349$, 290476).

Dari pengolahan menggunakan pusat Medoid baru diperoleh hasil sebagai Tabel berikut :

Tabel 4. Hasil Jarak Medoid Iterasi 2 tahun 2018

\begin{tabular}{lcccc}
\hline \multicolumn{1}{c}{ BULAN } & C1 & C2 & C3 & Jarak Dekat \\
\hline Januari & 219116 & 297786 & 48314 & 48314 \\
Februari & 103392 & 185675 & 143385 & 103392 \\
Maret & 95968 & 212727 & 144576 & 95968 \\
April & 48437 & 220105 & 200308 & 48437 \\
Mei & 0 & 196276 & 232468 & 0 \\
Juni & 196276 & 0 & 287840 & 0 \\
Juli & 85901 & 186766 & 160407 & 85901 \\
Agustus & 88502 & 201895 & 171296 & 88502 \\
September & 85117 & 193552 & 162640 & 85117 \\
Oktober & 94540 & 184349 & 150941 & 94540 \\
November & 86720 & 170628 & 178605 & 86720 \\
Desember & 232468 & 287840 & 0 & 0 \\
\hline
\end{tabular}

Dari table 4 dapat dilihat hasil jarak Medoid iterasi 2 untuk tahun 2018 yang akan digunakan untuk menentukan nilai Cost. Nilai Jarak Dekat ini yang akan digunakan sebagai letak cluster atau kelompok berdasarkan nilai terkecil perbaris.

Dari tabel 4 dapat diperoleh nilai Cost yaitu :

Cost $=(48314+103392+95968+48437+0+0+85901+88502+85117+94540+$ $86720)=73689$

g. Mencari Nilai $S$

Nilai $S$ diperoleh dengan cara mengurangi nilai Cost pada iterasi yang baru kepada iterasi awal. Jika nilai $\mathrm{S}<0$ maka pengolahan diteruskan dengan menggunakan nilai pusat medoid baru. Jika Nilai $\mathrm{S}>0$ atau nilai Cost iterasi baru lebih besar daripada nilai Cost iterasi lama maka proses dihentikan. Sehingga nilai $S$ diperoleh :

$\mathrm{S}=$ Nilai Cost Baru - Nilai Cost Lama $=736891-562147=174745$

Karena Nilai Cost Baru > Nilai Cost Lama, maka iterasi dihentikan.

h. Mencari Cluster atau Pengelompokan

Untuk menentukan Cluster diperoleh dengan menentukan nilai Cluster 1, 2 dan 3 terdekat dengan Nilai Jarak Distance sehingga diperoleh Cluster untuk tahun 2018 seperti pada tabel 5. Dari tabel 5 dapat dilihat hasil cluster yang diperoleh dari iterasi terakhir untuk tahun 2018. Diperoleh Cluster Rendah pada bulan Februari, Maret, April, Mei, Juli, Agustus, September, Oktober, dan November. Cluster Sedang pada bulan Juni, dan Cluster Tinggi pada bulan Januari dan Desember.

Untuk data tahun 2019 diperoleh hasil yang sama seperti data tahun 2018 dengan nilai $\mathrm{S}=$ 54677 iterasi terakhir pada tabel 6. 
Tabel 5. Cluster Tahun 2018

\begin{tabular}{lc}
\hline \multicolumn{1}{c}{ BULAN } & C1uster \\
\hline Januari & 3 \\
Februari & 1 \\
Maret & 1 \\
April & 1 \\
Mei & 1 \\
Juni & 2 \\
Juli & 1 \\
Agustus & 1 \\
September & 1 \\
Oktober & 1 \\
November & 1 \\
Desember & 3
\end{tabular}

Tabel 6. Hasil Jarak Medoid Iterasi 2 tahun 2019

\begin{tabular}{lcccc}
\hline BULAN & C1 & C2 & C3 & Jarak Dekat \\
\hline Januari & 180992 & 297406 & 48314 & 48314 \\
Februari & 45771 & 189547 & 145786 & 45771 \\
Maret & 71269 & 212458 & 144576 & 71269 \\
April & 77232 & 220532 & 200308 & 77232 \\
Mei & 86720 & 197030 & 232468 & 86720 \\
Juni & 171731 & 0 & 287545 & 0 \\
Juli & 54526 & 186842 & 160121 & 54526 \\
Agustus & 70213 & 201317 & 171296 & 70213 \\
September & 39999 & 186778 & 164239 & 39999 \\
Oktober & 48521 & 185755 & 147989 & 48521 \\
November & 0 & 171731 & 178605 & 0 \\
Desember & 178605 & 287545 & 0 & 0 \\
\hline
\end{tabular}

Dari tabel 6 diperoleh pengelompokkan atau cluster seperti pada tabel 7:

Tabel 7. Cluster Tahun 2019

\begin{tabular}{lc}
\multicolumn{1}{c}{ BULAN } & C1uster \\
\hline Januari & 3 \\
Februari & 1 \\
Maret & 1 \\
April & 1 \\
Mei & 1 \\
Juni & 2 \\
Juli & 1 \\
Agustus & 1 \\
September & 1 \\
Oktober & 1 \\
November & 1 \\
Desember & 3 \\
\hline \multicolumn{2}{c}{150} \\
\end{tabular}


Dari tabel 7 dapat dilihat hasil cluster yang diperoleh dari iterasi terakhir untuk tahun 2019. Diperoleh Cluster Rendah pada bulan Februari, Maret, April, Mei, Juli, Agustus, September, Oktober, dan November. Cluster Sedang pada bulan Juni, dan Cluster Tinggi pada bulan Januari dan Desember.

\subsection{Hasil Percobaan}

a. Implementasi Algoritma K-Medoids dengan RapidMiner

Pada bagian ini berisikan tampilan sistem dengan menggunakan Algoritma K-Medoids menggunakan RapidMiner. Berikut tampilan proses dari implementasi Algoritma K-Medoids :

1. Tahapan Importing Data

Tahapan awal yaitu pemasukkan data yang akan digunakan dalam penelitian. Penelitian ini menggunakan dua data yaitu data penjualan mie tahun 2018 dan data penjualan mie tahun 2019.

2. Tahapan Pengolahan Operator $K$-Medoids

Tahapan berikutnya memasukkan operator yang berkaitan dengan Algoritma $K$-Medoids kedalam Main Process pada RapidMiner untuk mencari hasil yang diperoleh. Proses yang dilakukan sebanyak dua kali yaitu data tahun 2018 dan tahun 2019

3. Hasil Pengolahan RapidMiner data tahun 2018

Hasil yang diperoleh dari pengolahan Algoritma K-Medoids pada RapidMiner untuk data tahun 2018 adalah sebagai berikut :

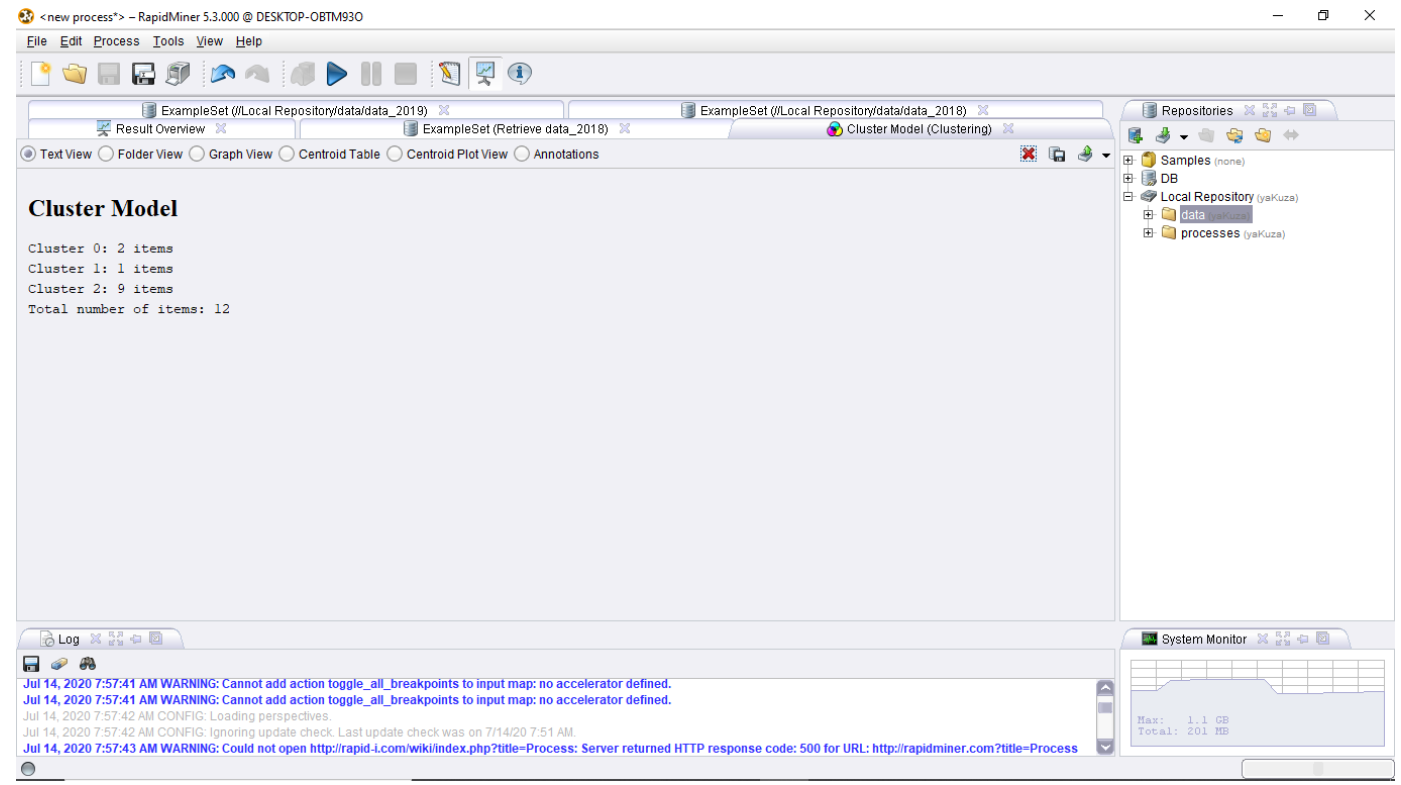

Gambar 3. Hasil Pengolahan RapidMiner Cluster Model

Gambar 3 menjelaskan hasil pengolahan RapidMiner dengan menampilkan Cluster Model dengan Cluster 0 sebagai Cluster Tinggi dengan jumlah 2 items, Cluster 1 sebagai Cluster Sedang dengan jumlah 1 items, dan Cluster 2 sebagai Cluster Rendah dengan jumlah 9 items. 


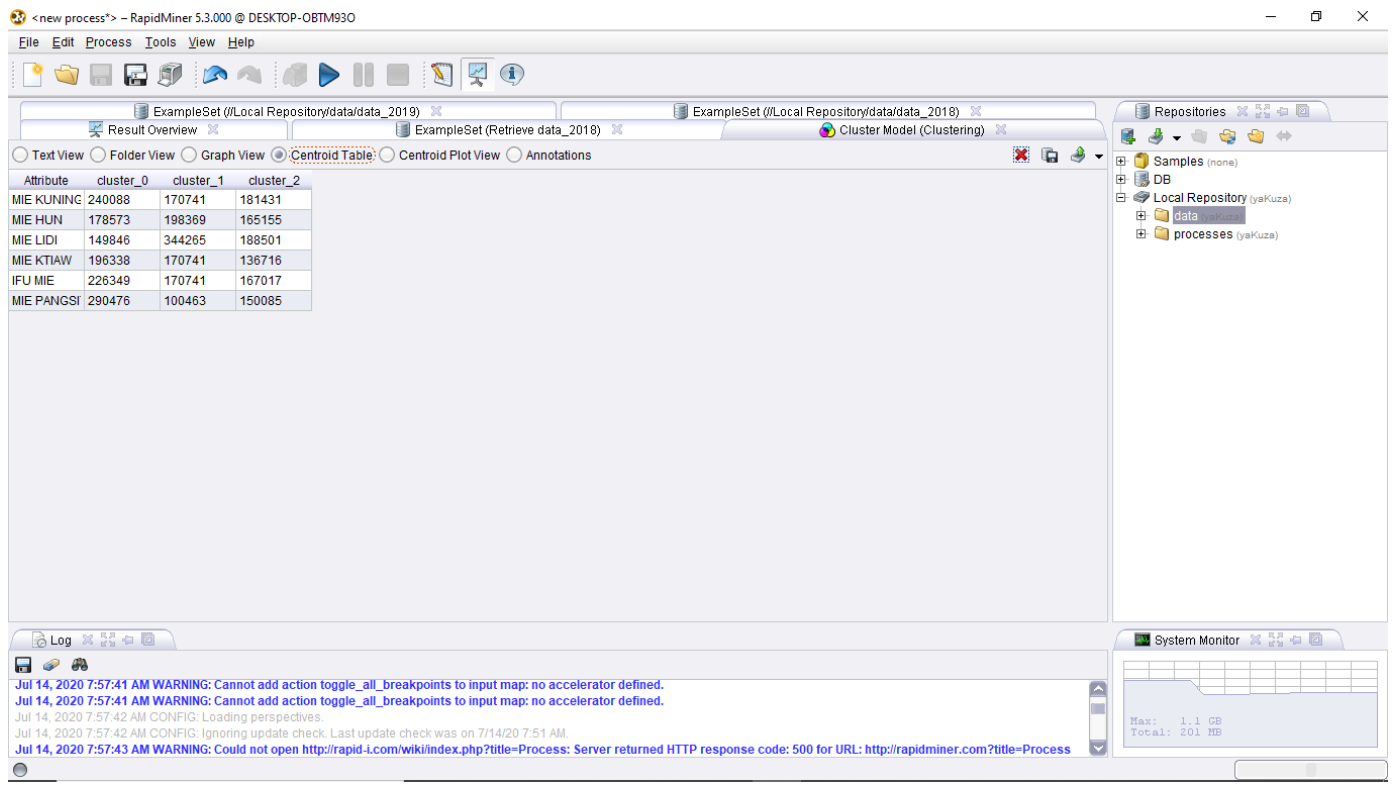

Gambar 4 Hasil Pengolahan RapidMiner Centroid Table

Gambar 4 menjelaskan hasil pengolahan RapidMiner dengan menampilkan hasil Centroid Table.

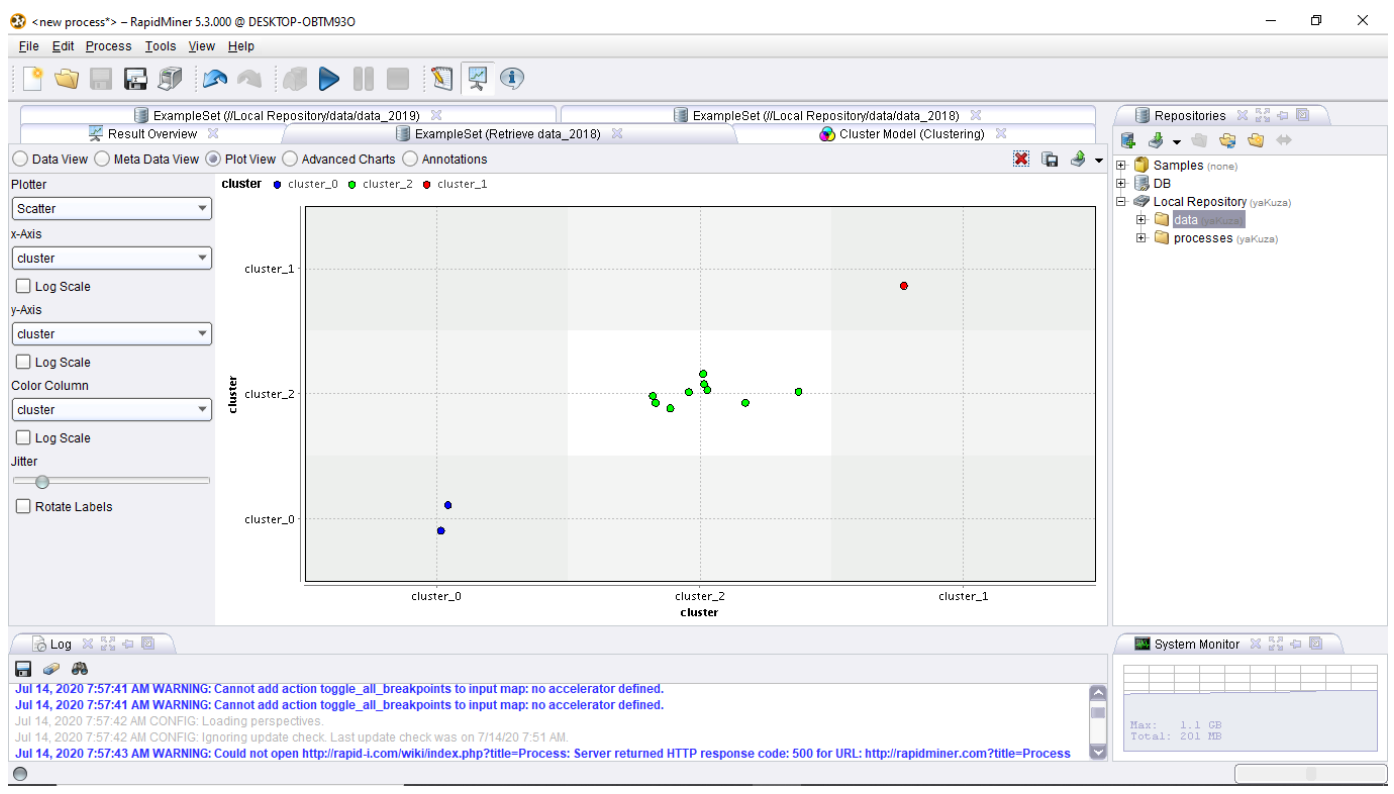

Gambar 5. Hasil Pengolahan RapidMiner Scatter

Gambar 5 menjelaskan hasil pengolahan data tahun 2018 pada tampilan Scatter. Gambar 5 dapat dilihat Clutser Tinggi berwarna biru dengan jumlah 2 items, Cluster Sedang berwarna Merah dengan jumlah 1 items dan Cluster Rendah berwarna hijau dengan jumlah 9 items.

4. Hasil Pengolahan RapidMiner data tahun 2019

Hasil yang diperoleh dari pengolahan Algoritma K-Medoids pada RapidMiner untuk data tahun 2019 adalah sebagai berikut : 


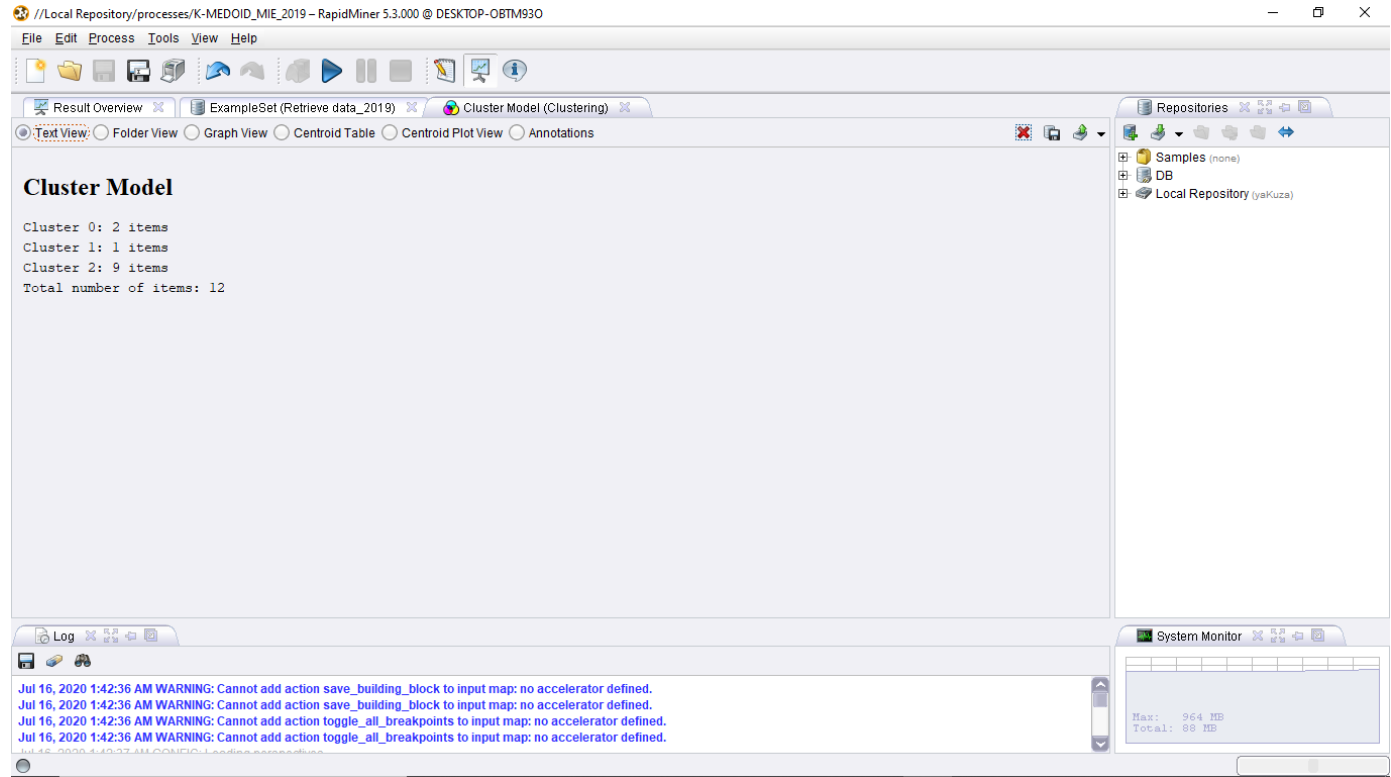

Gambar 6. Hasil Pengolahan RapidMiner Cluster Model

Gambar 6 menjelaskan hasil pengolahan RapidMiner dengan menampilkan Cluster Model dengan Cluster 0 sebagai Cluster Tinggi dengan jumlah 2 items, Cluster 1 sebagai Cluster Sedang dengan jumlah 1 items, dan Cluster 2 sebagai Cluster Rendah dengan jumlah 9 items

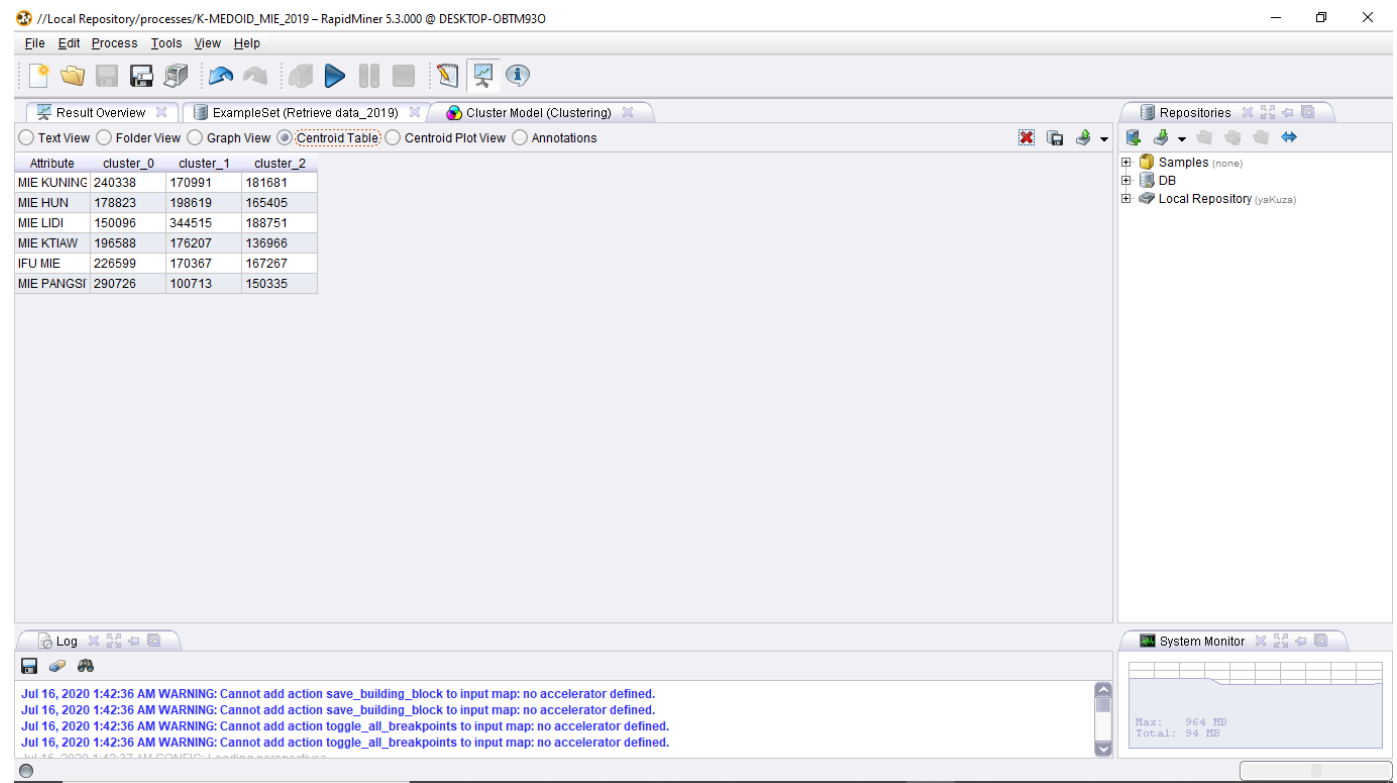

Gambar 7. Hasil Pengolahan RapidMiner Centroid Table

Gambar 7 menjelaskan hasil pengolahan RapidMiner dengan menampilkan hasil Centroid Table. 


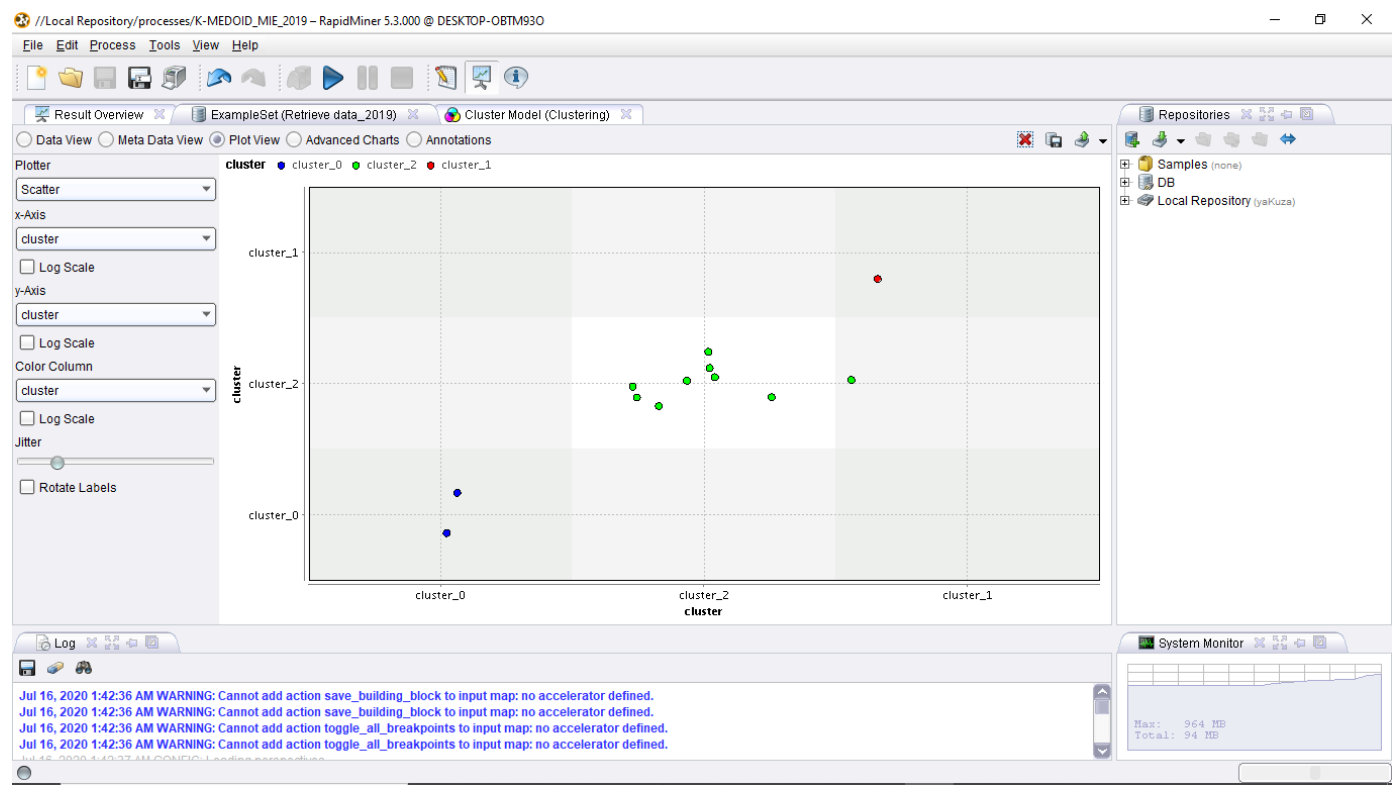

Gambar 8. Hasil Pengolahan RapidMiner Scatter

Gambar 8 menjelaskan hasil pengolahan data tahun 2019 pada tampilan Scatter. Gambar 8 dapat dilihat Clutser Tinggi berwarna biru dengan jumlah 2 items, Cluster Sedang berwarna Merah dengan jumlah 1 items dan Cluster Rendah berwarna hijau dengan jumlah 9 items.

\subsection{Pembahasan}

Hasil yang dilakukan penulis dalam perhitungan Algoritma K-Medoids diperoleh dengan hasil tahun 2018 Cluster Tinggi dengan jumlah 2 items pada bulan Januari dan Desember, Cluster Sedang dengan jumlah 1 items pada bulan Juni, dan Cluster Rendah dengan jumlah 9 items pada bulan Februari, Maret, April, Mei, Juli, Agustus, September, Oktober, dan November. Hasil tahun 2019 juga sama diperoleh Cluster Tinggi dengan jumlah 2 items pada bulan Januari dan Desember, Cluster Sedang dengan jumlah 1 items pada bulan Juni, dan Cluster Rendah dengan jumlah 9 items pada bulan Februari, Maret, April, Mei, Juli, Agustus, September, Oktober, dan November.

Hasil yang dilakukan dalam tools RapidMiner dalam perhitungan Algoritma K-Medoids diperoleh dengan hasil tahun 2018 Cluster Tinggi dengan jumlah 2 items pada bulan Januari dan Desember, Cluster Sedang dengan jumlah 1 items pada bulan Juni, dan Cluster Rendah dengan jumlah 9 items pada bulan Februari, Maret, April, Mei, Juli, Agustus, September, Oktober, dan November. Hasil tahun 2019 juga sama diperoleh Cluster Tinggi dengan jumlah 2 items pada bulan Januari dan Desember, Cluster Sedang dengan jumlah 1 items pada bulan Juni, dan Cluster Rendah dengan jumlah 9 items pada bulan Februari, Maret, April, Mei, Juli, Agustus, September, Oktober, dan November.

Artinya Hasil dari proses yang dilakukan penulis dan tools RapidMiner adalah sesuai dan sama dari proses yang dilakukan. Kesamaan hasil yang dilakukan dapat dijadikan salah satu solusi pemecahan dari permasalahan yang diteliti.

\section{KESIMPULAN}

Berdasarkan pembahasan di atas dapat disimpulkan bahwa Penerapan data mining menggunakan algoritma $K$-Medoids untuk untuk mencari pengelompokkan tingkat penjualan mie di Kota Pematangsiantar diperoleh dengan hasil tahun 2018 Cluster Tinggi dengan jumlah 2 items pada bulan Januari dan Desember, Cluster Sedang dengan jumlah 1 items pada bulan Juni, dan Cluster Rendah dengan jumlah 9 items pada bulan Februari, Maret, April, Mei, Juli, 
Agustus, September, Oktober, dan November. Serta penerapan data mining menggunakan algoritma $\mathrm{K}$-Medoids untuk untuk mencari pengelompokkan tingkat penjualan mie di Kota Pematangsiantar tahun 2019 juga sama diperoleh Cluster Tinggi dengan jumlah 2 items pada bulan Januari dan Desember, Cluster Sedang dengan jumlah 1 items pada bulan Juni, dan Cluster Rendah dengan jumlah 9 items pada bulan Februari, Maret, April, Mei, Juli, Agustus, September, Oktober, dan November.

Pengujian data pada Rapidminer5.3 dengan menggunakan algoritma KMedoids berhasil menampilkan dtinggi cluster dari hasil klasifikasi dengan presentase keakuratan sebesar 100\%

\section{DAFTAR PUSTAKA}

[1] D. F. Pramesti, M. T. Furqon, dan C. Dewi, "Implementasi Metode K-Medoids Clustering Untuk Pengelompokan Data Potensi Kebakaran Hutan / Lahan Berdasarkan Persebaran Titik Panas ( Hotspot )," J. Pengemb. Teknol. Inf. dan Ilmu Komput., vol. 1, no. 9, hal. 723-732, 2017.

[2] Z. Mustofa dan I. S. Suasana, "ALGORITMA CLUSTERING K-MEDOIDS PADA EGOVERNMENT BIDANG INFORMATION AND COMMUNICATION TECHNOLOGY DALAM PENENTUAN STATUS EDGI," vol. 9, hal. 1-10, 2018.

[3] D. F. Pramesti, Lahan, M. Tanzil Furqon, dan C. Dewi, "Implementasi Metode K-Medoids Clustering Untuk Pengelompokan Data," J. Pengemb. Teknol. Inf. dan Ilmu Komput., vol. 1, no. 9, hal. 723-732, 2017, doi: 10.1109/EUMC.2008.4751704.

[4] S. Defiyanti, M. Jajuli, dan N. Rohmawati, "Optimalisasi K-MEDOID dalam Pengklasteran Mahasiswa Pelamar Beasiswa dengan CUBIC CLUSTERING CRITERION," J. Nas. Teknol. dan Sist. Inf., vol. 3, no. 1, hal. 211-218, 2017, doi: 10.25077/teknosi.v3i1.2017.211-218.

[5] M. Ependi, Sopyan; Akbar, "implementasi Data Mining pada Penjualan Produk Elektronik Dengan Algotitma apriori," implementasi Data Min. pada Penjualan Prod. Elektron. Dengan Algotitma apriori, vol. 43, no. 5, hal. 10-23, 2013.

[6] H. Zayuka, S. M. Nasution, dan Y. Purwanto, "Perancangan Dan Analisis Clustering Data Menggunakan Metode K-Medoids Untuk Berita Berbahasa Inggris Design and Analysis of Data Clustering Using K-Medoids Method For English News," e-Proceeding Eng. , vol. 4, no. 2, hal. 2182-2190, 2017.

[7] H. Ningrum, E. Irawan, dan M. R. Lubis, "Implementasi Metode K-Medoids Clustering Dalam Pengelompokan Data Penyakit Alergi Pada Anak," Jurasik (Jurnal Ris. Sist. Inf. dan Tek. Inform., vol. 6, no. 1, hal. 130, 2021, doi: 10.30645/jurasik.v6i1.277.

[8] D. Listiyanti, Y. A. Syahbana, dan S. R. Henim, "Perancangan dan Implementasi Aplikasi Android Penentu Salient Area pada Video dengan Algoritma K-Medoids," vol. 2, no. 1, hal. 96-101, 2016, [Daring]. Tersedia pada: http://ars.ilkom.unsri.ac.id.

[9] A. A. D. Sulistyawati dan M. Sadikin, "Penerapan Algoritma K-Medoids Untuk Menentukan Segmentasi Pelanggan," Sistemasi, vol. 10, no. 3, hal. 516, 2021, doi: 10.32520/stmsi.v10i3.1332.

[10] S. Darma dan G. W. Nurcahyo, "Klasterisasi Teknik Promosi dalam Meningkatkan Mutu Kampus Menggunakan Algoritma K-Medoids," J. Inform. Ekon. Bisnis, vol. 3, hal. 89-94, 2021, doi: 10.37034/infeb.v3i3.87.

[11] J. Perbanas et al., “"Towards Economic Recovery by Accelerating Human Capital and Digital Tranformation' Perbanas Institute-SNAP_2021_FULL PAPER_41 ANALISIS DATA RISIKO NASABAH PADA BUSINESS CONTROL (BC) TOOLS MENGGUNAKAN RAPID MINER," hal. 178-189.

[12] B. G. Sudarsono, M. I. Leo, A. Santoso, dan F. Hendrawan, "Analisis Data Mining Data Netflix Menggunakan Aplikasi Rapid Miner," JBASE - J. Bus. Audit Inf. Syst., vol. 4, no. 1, hal. 13-21, 2021, doi: 10.30813/jbase.v4i1.2729.

[13] Ainurrohmah, "Akurasi Algoritma Klasifikasi pada Software Rapidminer dan Weka," Prisma, vol. 4, hal. 493-499, 2021, [Daring]. Tersedia pada: 
https://journal.unnes.ac.id/sju/index.php/prisma/.

[14] G. A. Pranata, H. Tanuwijaya, dan P. Sudarmaningtyas, "Rancang Bangun Sistem Informasi Permintaan Pembelian Barang Berbasis Web Di Stmik Stikom Surabaya," J. Sist. Inf. dan Komput. Akunt., vol. 3, no. 1, hal. 197-203, 2015.

[15] T. Informatika, F. I. Komputer, U. Al, A. Mandar, dan T. Sampah, "PENERAPAN UNIFIED MODELLING LANGUAGE ( UML ) PADA ANALISIS SISTEM SERTA PERANCANGAN DATABASE," vol. 6, hal. 170-177, 2021. 